\title{
Sikap Positif Para Remaja di Desa Buduk Kecamatan Mengwi, Kabupaten Badung terhadap Bahasa Bali
}

\author{
oleh : \\ Dr. Drs. I Nyoman Muliana, M. Hum. \\ inyomanmulianabali@gmail.com \\ Drs. Made Subur, M. Hum. \\ madesubur@gmail.com. \\ Drs. Anak Agung Gede Suarjaya, M. Hum. \\ suarjaya@gmail.com. \\ Prodi Sastra Inggris, Fakultas Sastra \\ Universitas Warmadewa
}

\begin{abstract}
Abstrak
Artikel yang bertemakan sikap positif para remaja di Desa Buduk, Kecamatan Mengwi, Kabupaten Badung terhadap bahasa Bali merupakan hasil sebuah penelitian. Penelitian tentang sikap bahasa ini tampak penting dilakukan untuk menelaah keberadaan bahasa Bali sebagai bahasa daerah di kalangan para remaja. Masalah yang dikaji dalam penelitian ini terdiri atas bentuk dan faktor sikap bahasa para remaja di Desa Buduk, Kecamatan Mengwi, Kabupaten Badung terhadap bahasa Bali. Teori yang diterapkan adalah Teori Sikap Bahasa yang dikemukakan oleh Ladegaard (2000). Hasil penelitian menunjukkan bahwa para remaja di Desa Buduk, Kecamatan Mengwi, Kabupaten Badung memiliki sikap bahasa yang positif terhadap bahasa Bali. Faktor-faktor yang mendukung sikap bahasa mereka itu dalah demografi dan loyalitas bahasa.
\end{abstract}

Kata Kunci : sikap bahasa, remaja, bahasa Bali

\section{A. Pendahuluan}

Bahasa menjadi suatu komponen penting bagi manusia. Hampir seluruh aktifitas manusia membutuhkan bahasa dan dapat dibayangkan seandainya manusia tidak memiliki bahasa. Chaer (2010) mengemukakan bahwa salah satu hakekat bahasa adalah manusiawi yang mencerminkan bahwa hanya manusia sebagai satu-satunya mahluk hidup yang memiliki bahasa. Sebagai bagian penting dalam hidupnya itu, manusia menggunakan bahasa untuk berbagai fungsi. Satu fungsi yang paling nyata adalah bahasa digunakan untuk menyampaikan ide atau pesan kepada orang lain. Di samping itu, bahasa juga digunakan untuk mengungkapkan suatu pesan atau makna yang menunjukkan nuansa imajinatif atau keindahan. Fungsi lain dari bahasa juga dapat dijumpai dalam bentuk penggunaan bahasa yang bertujuan untuk 
memelihara hubungan antara pembicara dengan pendengar atau penulis dengan pembaca.

Sebagai sebuah objek, bahasa dapat diklasifikasikan ke dalam beberapa jenis. Dilihat dari perkembangan hidup manusia dikenal dengan adanya jenis bahasa ibu, bahasa pertama, bahasa kedua, bahasa ketiga, dan seterusnya. jenis-jenis bahasa ini merupakan bahasa yang diperoleh seseorang pertama kali dari orangtunya dan seterusnya pada saat ia mengenal pergaulan di luar keluarganya atau lingkungannya dan ketika ia menempuh pendidikan. Jenis bahasa juga mengenal dengan adanya bahasa daerah, bahasa nasional, dan bahasa asing.jenis-jenis bahasa ini pada umunya berkenaan dengan batas wilayah suatu daerah atau negara. Salah satu jenis bahasa yang menjadi pokok bahasan dalam makalah ini adalah bahasa daerah. Menurut Jendra (2007), bahasa daerah merupakan suatu jenis bahasa yang digunakan di suatu daerah yang terdiri atas dua negara/bangsa.

Bahasa Bali merupakan salah satu bahasa daerah di Indonesia. Bahasa daerah ini digunakan oleh baik yang beretnis maupun yang tidak beretnis Bali yang sebagian besar tinggal di Bali. Sebagian di antara mereka tinggal di daerah-daerah lain di seluruh Indonesia, khususnya di daerah transmigrasi di berbagai daerah di Indonesia seperti di Sumatera, Sulawesi, dan Papua. Bahasa Bali memiliki tradisi lisan dan tulisan, dan dalam tradisi tulisannya itu bahasa Bali memiliki aksara tersendiri yang disebut Aksara Bali.
Sebagai sebuah bahasa daerah, bahasa Bali digunakan oleh para penuturnya dalam ranahranah tertentu, seperti ranah keluarga, pergaulan, adat, dan agama Hindu. Penggunaan bahasa Bali sebagai sarana komunikasi pada ranah keluarga dan ranah pergaulan dapat dijumpai pada masyarakat etnis Bali di daerah-daerah pedesaan. Di daerah-daerah seperti itu bahasa Bali digunakan oleh berbagai kelompok usia penutur, dari anak-anak hingga orang tua. Di daerah-daerah yang berkarakteristik perkotaan penggunaan bahasa Bali pada ranah-ranah keluarga dan pergaulan tampak sudah sangat berkurang. Pada ranah adat dan agama Hindu, bahasa Bali tampak digunakan di daerahdaerah baik di pedesaan maupun di perkotaan.

Keberadaaan bahasa daerah kini mulai dikeluhkan oleh banyak kalangan. Salah satu masalah yang mengemuka terhadap keberadaan bahasa daerah adalah semakin menurunnya jumlah penuturnya yang dijumpai di daerah-daerah yang justru menjadi asal penutur bahasa daerah itu. Banyak yang dijadikan argumen yang dikemukakan sebagai penyebab menurunnya jumlah penutur bahasa daerah. Darwis (2011) mengemukakan bahwa fungsi-fungsi bahasa daerah telah mengalami penurunan. Penurunan tersebut disebabkan menurut Darwis disebabkan oleh 2 hal pokok. Pertama, penutur bahasa daerah semakin berkurang akibat menguatnya fungsi bahasa Indonesia. Bahasa Indonesia memiliki kedudukan sebagai bahasa nasional dan bahasa resmi dalam kegiatan-kegiatan pendidikan dan pemerintahan yang dalam faktanya 
berpengaruh pada masyarakat Indonesia untuk menggunakannya dalam ranah-ranah yang tidak resmi. Kedua, penutur bahasa daerah juga disebabkan oleh semakin menguatnya arus globalisasi yang ditandai oleh mobilitias dan komunikasi manusia tanpa dibatasi oleh wilayah negara.

Sikap bahasa (language attitude) merupakan suatu unsur penting terkait dengan keberadaan bahasa termasuk bahasa daerah di samping faktor-faktor yang dikemukakan di atas. Secara konsep, sikap bahasa didefinisikan dalam berbagai deskripsi oleh para linguis. Jendra (1991) berpendapat bahwa setiap masyarakat sebagai penutur bahasa memiliki sikap-sikap tertentu terhadap bahasa mereka sendiri. Menurut Jendra, sikap bahasa adalah keadaan jiwa atau perasaan seseorang terhadap bahasanya sendiri atau bahasa orang lain. Ada anggota masyarakat yang agak malu memakai bahasanya dan ada pula yang biasa saja (dalam arti tidak memiliki rasa kebanggaan dan tidak pula merasa malu) dan ada pula yang merasa berbangga dengan bahasanya. Anderson (1974) mengemukakan bahwa sikap bahasa merupakan tata keyakinan atau kognisi yang relatif berjangka panjang yang dapat berkenaan dengan bahasa, objek bahasa, yang memengaruhi seseorang cenderung untuk bereaksi dengan cara tertentu yang disenanginya. Anderson menegaskan bahwa sikap bahasa bisa berwujud positif (kalau dinilai baik atau disukai) dan bisa berwujud negatif (kalau dinilai tidak baik atau tidak disukai).
Fenomena sikap bahasa juga dapat dijumpai pada para remaja di Desa Buduk, Kecamatan Mengwi, Kabupaten Badung. Di dalam penelitian ini, sikap bahasa mereka itu dikaitkan dengan dengan bahasa Bali yang merupakan bahasa daerah mereka. Penelitianpenelitian tentang sikap bahasa telah cukup banyak dilakukan. Misalnya, Wulandari, et al (2012) melakukan penelitian dengan judul Sikap Santri dalam Konteks Pemertahanan Bahasa Jawa dalam Proses Pengajaran di Pesantren (Studi Kasus pada PesantrenPesantren di Semarang). Wardani, et al (2013) melakukan penelitian dengan judul Sikap Bahasa Siswa terhadap Bahasa Indonesia Studi Kasus di SMA Negeri 1 Singaraja. Wardani, et al (2016) melakukan penelitian denga judul Pemilihan dan Sikap Bahasa Warga Bubuhan Banjar di Pontianak. Jurnal Pendidikan dan Pembelajaran Katulistiwa. Observasi awal penelitian ini menunjukkan bahwa para remaja tersebut memiliki sikap bahasa yang positif terhadap bahasa Bali. Penelitian ini secara khusus menelaah tentang bentuk sikap bahasa para remaja di Desa Buduk, Kecamatan Mengwi, Kabupaten Badung terhadap bahasa Bali yang disertai dengan faktor yang memengaruhinya. Penelitian ini merupakan penelitian Sosiolinguistik yakni tentang kajian tentang sikap bahasa teori Sikap Bahasa oleh Garvin dan Mathiot (1986) dan dengan menerapkan metode penelitian survei dan observasi partisipatif (Mahsun, 2005). 


\section{B. Pembahasan}

Hasil penelitian menunjukkan bahwa para remaja di Desa Buduk, Kecamatan Mengwi, Kabupaten Badung memiliki sikap bahasa yang sangat positif terhadap bahasa Bali. Temuan tersebut dapat dipaparkan pada analisis data survei penelitian ini yang menunjukkan sikap bahasa para remaja di Desa Buduk, Kecamatan Mengwi, Kabupaten Badung terhadap bahasa Bali dalam tiga afektif, dan konatif.

Sikap bahasa secara kognitif merupakan kompnen sikap bahasa yang berbentuk pandangan atau pendapat seseorang terhadap suatu bahasa. Dalam komponen ini, seseorang bisa memandang suatu bahasa sebagai suatu bidang yang mudah/sulit, bagus/buruk, dan sejenisnya. Di dalam penelitian ini, sikap bahasa para remaja di Desa Buduk, Kecamatan Mengwi, Kabupaten komponen sikap bahasa, yakni kognitif,

Badung secara kognitif tetrhadap bahasa Bali itu digali dengan menggunakan pernyataanpernyataan berikut ini.

1) Bahasa Bali penting untuk menunjukkan identitas kita sebagai orang suku Bali.

2) Bahasa Bali itu tidak sulit dan banyak kosa katanya yang mudah saya jumpai di sekitar saya.

3) Orang yang berbicara dalam bahasa Bali itu tidak tampak kampungan/kolot.

4) Kita orang Bali tidak menggunakan bahasa Bali berarti kita tidak menghormati warisan leluhur.

Hasil analisis data survei tentang sikap bahasa para remaja di Desa Buduk, Kecamatan Mengwi, Kabupaten Badung secara kognitif tetrhadap bahasa Bali dapat disajikan pada tabel berikut ini.

\section{Tabel 1}

Sikap para Remaja di Desa Buduk, Kecamatan Mengwi, Kabupaten Badung Bahasa secara Kognitif

\begin{tabular}{|c|c|c|c|c|c|}
\hline \multirow{2}{*}{ Pernyataan } & \multicolumn{5}{|c|}{ Tanggapan } \\
\cline { 2 - 6 } & SS & S & N & TS & STS \\
\hline 1 & $25 \%$ & $75 \%$ & $0 \%$ & $0 \%$ & $0 \%$ \\
\hline 2 & $21,7 \%$ & $13 \%$ & $0 \%$ & $45,3 \%$ & $20 \%$ \\
\hline 3 & $63 \%$ & $15,3 \%$ & $0 \%$ & $11,7 \%$ & $1 \%$ \\
\hline 4 & $70 \%$ & $26,4 \%$ & $0 \%$ & $3 \%$ & $0.6 \%$ \\
\hline
\end{tabular}

Keterangan :

$\begin{array}{ll}\text { SS } & \text { : sangat setuju } \\ \text { S } & : \text { setuju } \\ \text { N } & : \text { netral } \\ \text { TS } & : \text { tidak setuju } \\ \text { STS } & \text { : sangat tidak setuju }\end{array}$

Tabel 1 merupakan hasil analisis data survei tentang sikap bahasa para remaja di Desa Buduk, Kecamatan Mengwi, Kabupaten Badung secara kognitif yang menunjukkan 
persentase tinggi terhadap persetujuan para responden terhadap lima pernyataan kuesioner sikap bahasa secara kognitif kecuali pernyataan 2 yang menyatakan bahwa bahasa Bali adalah bahasa yang sulit dengan kosakatanya mudah dijumpai. Persentase tinggi terhadap pernyataan ini mencerminkan bahasa Bali masih terkesan sebagai bahasa yang memang sulit bagi kalangan para remaja di Desa Buduk, Kecamatan Mengwi, Kabupaten Badung.

Sikap bahasa secara afektif merupakan komponen sikap bahasa seseorang yang berkenaan dengan perasaan. Dalam komponen sikap bahasa ini, seseorang bisa memiliki perasaan suka/tidak suka, senang/tidak senang, malu/tidak malu dan sejenisnya terhadap suatu bahasa. Sikap bahasa secara afektif di dalam penelitian ini digali melalui pernyataanpernyataan berikut ini.

1) Saya lebih suka menggunakan bahasa bahasa Bali untuk bercakap-cakap dengan teman atau saudara sesama orang bali.

2) Saya tidak malu menggunakan bahasa Bali khususnya di hadapan orang suku lain walaupun saya menjadi pusat perhatian mereka.

3) Saya tidak suka disapa dalam bahasa lain selain bahasa Bali.

4) Saya lebih suka mendengar berita radio atau menonton televisi yang menggunakan bahasa Bali daripada berita-berita yang menggunakan bahasa lain selain bahasa Bali.

\section{Tabel 2}

Sikap Bahasa secara Afektif

\begin{tabular}{|c|c|c|c|c|c|}
\hline \multirow{2}{*}{ Pernyataan } & \multicolumn{5}{|c|}{ Tanggapan } \\
\cline { 2 - 6 } & SS & S & N & TS & STS \\
\hline 1 & $85 \%$ & $10,3 \%$ & $0 \%$ & $4 \%$ & $0,7 \%$ \\
\hline 2 & $91,7 \%$ & $3 \%$ & $0 \%$ & $5 \%$ & $0,3 \%$ \\
\hline 3 & $63 \%$ & $35 \%$ & $0 \%$ & $2 \%$ & $0 \%$ \\
\hline 4 & $0,2 \%$ & $0,6 \%$ & $0 \%$ & $28,2 \%$ & $71 \%$ \\
\hline
\end{tabular}

Keterangan :

$\begin{array}{ll}\text { SS } & \text { : sangat setuju } \\ \text { S } & \text { : setuju } \\ \text { N } & \text { : netral } \\ \text { TS } & \text { : tidak setuju } \\ \text { STS } & \text { : sangat tidak setuju }\end{array}$

Dari empat pernyataan yang diberikan dalam sikap bahasa secara afektif dalam kuesioner penelitian ini, terdapat hasil analisis yang menunjukkan sikap bahasa yang sangat positif dengan persentase pilihan tinggi terhadap bentuk tanggapan sangat setuju dan setuju untuk pernyataan 1, 2, dan 3. Akan tetapi, untuk pernyataan 4 kuesioner sikap bahasa ini tampak para responden cenderung 
tidak memilih bahasa Bali sebagai bahasa untuk informasi atau berita di media massa.

Sikap bahasa secara konatif merupakan komponen sikap bahasa yang konkret jika dibandingkan dengan dua komponen sikap bahasa yang lainnya. Komponen sikap bahasa secara konatif berwujud dalam bentuk perilaku (behaviour) dalam menggunakan suatu bahasa. Di dalam penelitian ini, sikap bahasa para remaja di Desa Buduk, Kecamatan Mengwi, Kabupaten Badung secara konatif terhadap bahasa Bali digali melalui pernyataan-pernyatan berikut ini.
1) Kalau diajak bercakap-cakap oleh orang Bali dengan bahasa lain selain bahasa Bali, maka saya akan menjawabnya dengan bahasa Bali.

2) Saya akan menegur orang Bali yang bercakap-cakap dengan bahasa Indonesia.

3) Saya akan mematikan televisi atau radio yang menyiarkan berita tanpa bahasa Bali

4) Kelak kalau punya anak, saya akan mengajarkannya bahasa Bali.

\section{Tabel 3}

Sikap Bahasa secara Konatif

\begin{tabular}{|c|c|c|c|c|c|}
\hline \multirow{2}{*}{ Pernyataan } & \multicolumn{5}{|c|}{ Tanggapan } \\
\cline { 2 - 6 } & $\mathrm{SS}$ & $\mathrm{S}$ & $\mathrm{N}$ & $\mathrm{TS}$ & STS \\
\hline 1 & $82 \%$ & $10,3 \%$ & $0 \%$ & $4,3 \%$ & $3,4 \%$ \\
\hline 2 & $28,7 \%$ & $13 \%$ & $0 \%$ & $55 \%$ & $3,3 \%$ \\
\hline 3 & $0 \%$ & $5,3 \%$ & $0 \%$ & $68,7 \%$ & $26 \%$ \\
\hline 4 & $80 \%$ & $16,5 \%$ & $0 \%$ & $2 \%$ & $2,5 \%$ \\
\hline
\end{tabular}

Keterangan :

$$
\begin{array}{ll}
\text { SS } & \text { : sangat setuju } \\
\text { S } & \text { : setuju } \\
\text { N } & \text { : netral } \\
\text { TS } & \text { : tidak setuju } \\
\text { STS } & \text { : sangat tidak setuju }
\end{array}
$$

Pernyataan-pernyataan dalam kuesioner sikap bahasa secara konatif yag dibuat di dalam penelitian ini dibuat untuk merepresentasikan komponen sikap bahasa yang konkret. Pesan yang dimaksudkan pada tiap-tiap pernyataan tersebut menunjukkan aktivitas sehingga responden dapat memahami bahwa mereka diarahkan pada suatu kegiatan. Dari empat pernyataan yang diajukan pada sikap bahasa konatif dalam penelitian ini tampak memperoleh tanggapan yang sangat positif dari para responden kecuali pernyataan 3 yang menyatakan bahwa mereka tidak akan mematikan pesawat televisi atau radio yang menyiarkan berita dengan bahasa selain bahasa Bali.

Penelitian ketiga sikap bahasa para remaja di Desa Buduk, Kecamatan mengwi, Kabupaten Badung juga disertai dengan metode penelitian observasi partisipatif dengan 
data dalam bentuk percakapan para remaja itu. Berikut ini disajikan dua buah percakapan untuk melengkapi analisis data survei dan dipergunakan sebagai representasi

Percakapan 1 :

$\begin{array}{ll}\text { Topik } & \text { : Jualan } \\ \text { Lokasi } & : \text { Di rumah salah satu } \\ \text { informan } & \\ \text { Partisipan } & : \text { Empat remaja laki-laki } \\ \text { Iwan } & : \text { Peng medagang jani. } \\ & \text { Peng sekarang jualan. } \\ \text { Tisen } & : \text { Tamune kone konya cancel. } \\ & \quad \text { Tamunya semua batal. } \\ \text { Iwan } & : \text { Jani konya lockdown. Nyen }\end{array}$

bani mai.

Sekarang semua lockdown.

Siapa berani kesini.

Adi : Liu nak medagang jani.

Banyak yang jualan

sekarang.

Iwan : Keweh mase nok.

Sulit juga ya.

Wika : To Mita liu timpalne ngorin ngendorse.

Itu Mita banyak temannya yang nyuruh ngendorse.

Percakapan 1 terjadi di rumah seorang informan di suatu malam ketika tiga temannya datang berkunjung dengan tujuan hanya untuk bertemu biasa. Mereka semua adalah laki-laki. Dalam kesempatan seperti itu, topik yang mereka perbincangkan juga tidak menentu, dan salah satunya adalah satu topik seperti yang tampak dalam percakapan $1 \mathrm{itu}$. Suasana percakapan di antara empat remaja laki-laki di Desa Buduk, Kecamatan mengwi, Kabupaten Badung itu tampak sangat santai. Jenis bahasa yang mereka gunakan dalam percakapan tersebut secara keseluruhan adalah bahasa Bali ragam biasa. Penggunaan bahasa Bali dalam percakapan itu tampak disertai dengan penggunaan unsur-unsur bahasa asing (bahasa Inggris), seperti cancel, lockdown, dan ngendorse yang disebabkan oleh belum adanya padanannya dalam bahasa Bali dan kata-kata tersebut tampak sudah lumrah di antara partisipan percakapan.

Percakapan 2 :

Topik : Sekolah Gita

Lokasi : Di rumah informan

Partisipan : satu remaja laki-laki dan dua remaja perempuan

Ade : Gitanya ndak pulang dia?

Ika : Ndak. Belum dikasi pulang.

Ade : Kalau nelpon dikasi?

Ika : Sering. Tadi dia messenger.

Dinda : Sekolah apa itu, Mbok Ka?

Ika : Pelayaran.

Ade : Di kapal cruise?

Ika : Ndak. Katanya di kapal ikan.

Dinda : Wah hebat Mbok Gita.

Percakapan 2 terjadi di rumah seorang informan, seorang remaja laki-laki yang ketika perakapan terjadi berkumpul santai di suatu sore sambil bercengkrama dengan dua remaja perempuan. Mereka bertiga memiliki tempat tinggal yang saling berdekatan yang tanpa dibatasi tempbok pembatas. Topik yang 
mereka perbincangkan dalam percakapan itu adalah tentang sekolah Gita, salah satu teman mereka. Dalam percakapan itu tampak bahasa yang mereka gunakan adalah bahasa Indonesia yang tampak disebabkan oleh latar belakang keluarga mereka yang tergolong sebagai keluarga dengan status sosial kelas atas. Dalam penggunaan bahasa Indonesia dalam percakapan itu mereka juga tampak menggunakan unsur-unsur bahasa Inggris, yakni messenger dan cruise yang tampak mereka gunakan karena padanannya belum ada dalam bahasa Indonesia dan kata-kata tersebut tampak sudah lumrah atau sudah dipahami oleh partisipan percakapan.

Faktor-faktor yang memengaruhi sikap positif para remaja di Desa Buduk, Kecamatan Mengwi, Kabupaten Badung terhadap bahasa Bali adalah demografi dan loyalitas bahasa. Yang dimaksud dengan faktor demografi adalah situasi sebaran para remaja di Desa Buduk, itu masih tampak kerap. Mereka tinggal di rumah-rumah yang satu dengan yang lainnya masih terkonsentrasi sehingga peluang menggunakan bahasa Bali di antara mereka masih sangat tinggi. Di samping itu, faktor penting yang memengaruhi positifnya sikap bahasa para remaja di Desa Buduk terhadap bahasa Bali adalah loyalitas yang mereka tunjukkan dengan tetap menggunakan bahasa Bali dalam komunikasi mereka dengan sesama orang Bali.

\section{Kesimpulan}

Kesimpulan yang diperleh dalam penelitian ini adalah para remaja di Desa
Buduk, Kecamatan Mengwi, Kabupaten Badung memiliki sikap bahasa yang positif terhadap bahasa Bali. Sikap positif para remaja tersebut terhadap terwujud pada tiga komponen sikap bahasa yang diperoleh melalui hasil analisis data survei penelitian ini. Faktor-faktor yang mendukung sikap bahasa mereka itu terhadap bahasa Bali adalah demografi dan loyalitas bahasa. Faktor demografi merupakan suatu situasi sebaran para remaja di Desa Buduk, itu masih tampak kerap. Di desa iu mereka tinggal di rumahrumah yang satu dengan yang lainnya masih terkonsentrasi yang memberi peluang yang sangat tinggi bagi mereka untuk menggunakan bahasa Bali. Di samping itu, faktor penting yang memengaruhi positifnya sikap bahasa para remaja di Desa Buduk terhadap bahasa Bali adalah loyalitas bahasa yang ditunjukkan oleh para remaja di Desa Buduk, Kecamatan Mengwi, Kabupaten Badung bentuk penggunaan bahasa Bali secara konsisten dalam komunikasi mereka sehari-hari dengan sesama orang Bali

\section{Dasftar Pustaka}

Chaer, Abdul, 2011. Psikolinguistik Kajian Teoretik. Jakarta : PT. Rineka Cipta.

Jendra, I W. 2007, Sosiolinguistik Teori dan Penerapannya. Surabaya : Penerbit Paramita.

Darwis, M. 2011. Nasib Bahasa Daerah di Era Globalisasi : Peluang dan Tantangan https://core.ac.uk/download/pdf/25485 327.pdf . 
Garvin, Paul L. dan Madeline Mathiot, 1956. The Urbanization of the Guarani

Language: A Problem in Language and Culture, dalam Men and Culture: Selected Papers of the Fifth International Congress of Anthropological and Ethnological Sciences. Philadelphia : University of Pennsylvania Press.

Ladegaard, H.J. 2000. Language Attitudes and sociolinguistic behaviour : Exploring attitude-behaviour relations in language in Journal of Sociolinguistics Number 2. USA : Blackwell Publishers Ltd.

Mahsun, M.S., 2005. Metode Penelitian Bahasa Tahapan, Strategi. Metode, dan Tekniknya. Jakarta : PT. RajaGrafindo Persada.

Wardani, A.K.D.K., Gosong, M., Artawan, G. 2013. Sikap Bahasa Siswa terhadap Bahasa Indonesia Studi Kasus di SMA Negeri 1 Singaraja: https://www.neliti.com/publications/ 206910/sikap-bahasa-siswaterhadap-bahasa-indonesia-studikasus-di-sma-negeri-1-singara

Wardani, D.I., Sukamto, Simanjuntka, H. 2016. Pemilihan dan Sikap Bahasa Warga Bubuhan Banjar di Pontianak. Jurnal Pendidikan dan Pembelajaran Katulistiwa. Vo. 5. No. 5. pp. 1-17. Tahun 2016. Diakses dari : https://jurnal.untan.ac.id/index.php/j pdpb/article/view/15398

Wulandari, et al. 2012. melakukan penelitian dengan judul Sikap Santri dalam Konteks Pemertahanan Bahasa Jawa dalam Proses Pengajaran di Pesantren (Studi Kasus pada Pesantren-Pesantren di Semarang) : http://eprints.undip.ac.id/43120/1/LA
PORAN_AKHIR_Penelitian_pembi naan.pdf 